\title{
Intra-Hospital Committee for Donation of Organs and Tissues for Transplant: ethical issues
}

\author{
Comissão Intra-Hospitalar de Doação de Órgãos e Tecidos para Transplante: questões éticas
Comisión Intrahospitalaria de Donación de Órganos y Tejidos para Trasplante: cuestiones éticas

Josiane Cappellaro ${ }^{1}$, Rosemary Silva da Silveira ${ }^{1}$, Valéria Lerch Lunardii ${ }^{1}$, Lisiane Van Ommeren Corrêa ${ }^{1}$, Marina Landarin Sanchez ${ }^{1}$, Isabela Saioron ${ }^{1}$

The objective of this study was to demonstrate ethical aspects involved in the donation, collection and transplantation of organs and tissues through the experiences of workers in an intra-hospital committee for donation of organs and tissues for transplant. Exploratory qualitative research developed with eleven health workers. Data collection was performed at a university hospital in Pelotas, RS, Brazil, in the period of January-March 2010, through interviews. Data analysis resulted in the following categories: understanding of brain death diagnosis as an ethical issue; and, ethical issues experienced by workers in the relationship established with the family. It was concluded that such situations instigate workers to reflect on their attitudes, values, and their role as a health team member and protector of lives.

Descriptors: Organ Transplantation; Workers; Ethics.

Este estudo teve como objetivo evidenciar os aspectos éticos envolvidos na doação, captação e transplante de órgãos e tecidos pelas vivências dos trabalhadores de uma Comissão Intra-Hospitalar de Doação de Órgãos e Tecidos para Transplante. Pesquisa qualitativa do tipo exploratória, desenvolvida com onze trabalhadores da saúde. A coleta de dados foi realizada em um hospital universitário de Pelotas, RS, Brasil, de janeiro a março de 2010, por meio de entrevistas. A análise dos dados conduziu às seguintes categorias: a compreensão do diagnóstico de morte encefálica como questão ética; e aspectos éticos vivenciados pelos trabalhadores na relação estabelecida com a família. Concluiu-se que tais situações instigam o trabalhador a questionar-se sobre suas atitudes, valores e a refletir sobre o seu fazer como membro de uma equipe da saúde e protetor de vidas.

Descritores: Transplante de Órgãos; Trabalhadores; Ética.

El objetivo del estudio fue evidenciar los aspectos éticos involucrados en la donación, búsqueda y trasplante de órganos y tejidos a través de las experiencias de los trabajadores de una Comisión Intrahospitalaria de Donación de Órganos y Tejidos para Trasplante. Investigación cualitativa, del tipo exploratoria, desarrollada con once trabajadores de la salud. La recogida de datos fue en hospital universitario de Pelotas, RS, Brasil, de enero a marzo de 2010, por medio de entrevistas. El análisis de los datos condujera a las siguientes categorías: comprensión del diagnóstico de muerte cerebral como cuestión ética; y aspectos éticos experimentados por los trabajadores en relación establecida con la familia. En conclusión, tales situaciones instigan al trabajador a preguntarse acerca de las actitudes, valores y a reflexionar sobre lo que hace como miembro de un equipo de salud y protector de vidas.

Descritores: Transplante de Órganos; Trabajadores; Ética.

\footnotetext{
${ }^{1}$ Universidade Federal do Rio Grande. Rio Grande, RS, Brazil. 


\section{Introduction}

Organ, tissues and body parts transplants have been an existing practice in Brazil since the 1960's and constitute an alternative when conventional treatments are no longer effective to remedy diseases that cause complete failure of an organ or tissue. The donation of organs and tissues for transplant is not a highly technical-medical problem, consisting however of ethical social aspects such as the establishment of safe criteria for brain death diagnosis, previously expressed consent, and donor's and receiver's family clarifications $^{(1)}$.

Among these aspects that guide organ transplants, confirmed diagnosis of brain death is essential since it represents an irreversible medical condition in which the brain and brainstem functions are utterly compromised, making it impossible to maintain organs without life support equipment and causing numerous complications after brain stoppage $\mathrm{e}^{(2)}$.

Although early detection of brain death is essential for organ donation achievement, there are some physiological changes caused by brain death such as hypotension and hypothermia that can compromise a likely effective transplantation. Therefore, the health team in charge must be prepared and able to prevent such complications and maintain viable organs for probable donations ${ }^{(3)}$.

In Brazil, where there is a possibility of donation due to brain death diagnosis, family consent is necessary prior to the start of the process, which emphasizes the importance of the family approach requiring medical and scientific technical training of medical staff. However, it is noteworthy that family support/assistance and the sensitivity of an IntraHospital Committee for Donation of Organs and Tissues for Transplant may influence the decision of the potential donor's family. The decision of donating may not only be linked to the conduct of the interviewer because factors such as culture, access to information and previous consent expressed by the potential donor should also be considered ${ }^{(4)}$.

In order to make the organ harvesting process viable, the existence and effective functioning of an Intra-Hospital Committee for Donation of Organs and Tissues for Transplant is required in all public, private and philanthropic hospitals with more than 80 beds/ accommodations. Enabling brain death diagnosis according to Federal Medical Council resolutions and ensuring a fast and efficient process within strict ethical and moral parameters can be highlighted among the functions of the Intra-Hospital Committee for Donation of Organs and Tissues for Transplant $t^{(5)}$.

The lack of brain death notification, failure to maintain organs for collection ${ }^{(1)}$, and family refusal ${ }^{(6-7)}$ are the main factors impeding the effectiveness of organ donation. In Brazil, for every eight potential donors only one is notified, and only $20 \%$ of these are effective multiple organ donors ${ }^{(8)}$.

An Intra-Hospital Committee for Donation of Organs and Tissues for Transplant is necessary to facilitate the process of identifying potential donors, implementing protocols for carrying out diagnostic tests, proving and notifying brain death conditions, raising family awareness and thereby reducing possible obstacles to successfully conduct transplants in Brazil. Nevertheless, it can be observed that funding to form such committees is difficult to obtain due to the high costs of facilities, equipment and qualified staff ${ }^{(9)}$.

The health care professional involved in the harvesting process must have skills that enable them to clarify any doubts that the family may have on aspects relating to the collection process, brain death, procedures and technology ${ }^{(10)}$. Thus, it is considered necessary that each professional feels a sense of duty, responsibility and commitment emerging from constructing an ethical process. Greater involvement and awareness of professionals from different areas in order to develop multidisciplinary and effective work is also necessary ${ }^{(11)}$.

It is believed that the experience and knowledge of an Intra-Hospital Committee can contribute and 
facilitate health care members to understand their role and duties, and also encourage other institutions that want to deploy and facilitate the donationtransplant process, regarding compliance with legal requirements and for patients awaiting donations of an organ and a new opportunity in life. Thus, it was the aim of this study to highlight the ethical aspects involved in the donation, collection and transplant of organs and tissues from experiences of workers in the Intra-Hospital Committee for Donation of Organs and Tissues for Transplant of a public hospital in the far south of Brazil.

\section{Methods}

Thisis a qualitativeresearch study of exploratory type, developed with eleven health professionals: a doctor, seven nurses, a social worker and two overnight supervisors, all of whom act as members of the Intra-Hospital Committee for Donation of Organs and Tissues for Transplant in a public hospital in the far south of Brazil. The inclusion criterion was to be an acting member of this committee, regardless of service time (since their professional experience, no matter how small, will contribute to the achievement scope of this study).

Initially, a document providing clarification on the study was delivered to the members of the Intra-Hospital Committee for Donation of Organs and Tissues for Transplant inviting them to join the research by explaining the objectives and proposed methodology; requesting their consent form, ensuring respect for ethical aspects, such as the right to privacy, as well as ensuring respect and the anonymity of participants. To guarantee anonymity, research members were identified as subjects, followed by ordinal numbers.

Data collection was conducted from January to March 2010 using an interview technique performed in a private place, as per choice of the respondent. The interviews were previously scheduled with the workers, according to their availability and upon their release and statement for the meeting and with their consent for the use of a recording device. The interview consisted of open-ended questions, encouraging the participants to express the important dimensions about their performance in the committee, their feelings ${ }^{(12)}$, values, ways of being and acting through their experiences of the Intra-Hospital Committee for Donation of Organs and Tissues for Transplant, thereby realizing the significance of being integrated in the donation-transplant process. The information obtained in the interviews were recorded, transcribed, registered and validated by the study participants.

During the analysis process, the data were organized in order to develop a method to classify them and index them. They were subsequently converted into pre-categories; that is, a classification scheme was developed by grouping similar data in order to facilitate the search for meaning and deeper understanding, allowing for better overall organization and control. In this sense, there was the data analysis from the organization and the extraction of its meaning in the research, which required intensive activity, the use of creativity and sensitivity to facilitate the interpretation of the findings ${ }^{(12)}$. Data analysis led to the following categories: understanding the diagnosis of brain death as an ethical issue; and ethical aspects experienced by workers in the relationship established with the family. The study was approved by the Research Ethics Committee of the Health Area, of the opinion 63/09 of the Federal University of Rio Grande.

\section{Results}

\section{Category 1: Understanding brain death diagnosis as an ethical issue}

One of the ethical dilemmas that integrates the Intra-Hospital Committee for Donation of Organs and Tissues for Transplant refers to the understanding 
of the diagnosis of brain death. In relation to brain death we often hear that famous phrase: "I do not know why they are taking a dead patient to the Intensive Care Unit" (Subject 2). The understanding of brain death is key because it is hard for the medical team and for the family (Subject 7).

The understanding of the diagnosis of brain death is not only necessary for health care professionals, but especially for the family, because the use of equipment to maintain a brain dead patient's clinical condition can mask the perception of this process. The most important ethical issue is to understand brain death, for the family to understand that the patient is dead, even though the patient is lying in bed breathing, their heart is beating and warm, it is hard, even for us professionals sometimes (Subject 3).

The difficulty of a health professional, in general, is to understand the process for viable organ maintenance in situations where the patient is braindead. It is one of the most present ethical dilemmas in the Intra-Hospital Committee for Donation of Organ and Tissues for Transplant. Our scintigraphy is done elsewhere; it depends on patient transportation, what if the patient dies on the way? If they die on the way you should do resuscitation, you still have a potential donor, you can still use a kidney, corneas, so attempt resuscitation! These inter-colleague interactions, I won't say they are ethically complicated, are often unnecessary and prove ignorance of process, diagnosis and maintenance procedures (Subject 2).

Category 2: Ethical aspects experienced by workers in the Intra-Hospital Committee for Donation of Organs and Tissues for Transplant in their relationship with family

One of the most frequent ethical dilemmas during fundraising activities and donation emerges from the family's refusal to donate the organs of patients with a diagnosis of brain death. A major ethical problem is what to do to confront a family's refusal to donate. It is their right to accept it or not, but then, what to do? Ethically, turning off, legally, not turning it off, this is the main conflict, to wait for someone who is breathing but died in the intensive care unit, while losing another recoverable patient (Subject 2). Another pertinent question is when the family does not accept the donation, switching off the devices is an extremely complicated ethical issue, so you have to know how to clearly differentiate brain death from euthanasia, understanding the process (subject 3). When the family denies donation, only one of the doctors turns off the equipment when brain death is detected, according to the medical resolution, they can turn it off (Subject 4).

One of the most difficult ethical issues to be addressed regarding brain death diagnosis is the family agreeing to the donation and then changing their opinion during the process. In relation to diagnosed brain death and the family's refusal to donate, we had a confusing case in our hospital where the parents wanted to turn off the devices because they had already arranged the child's funeral and at the last moment they did not want to allow organ donation because the funeral was already organized. The doctors of the intensive care unit said they would not turn the equipment off, then it got really confusing because if donations had been made, the child would be considered dead and could be buried, but if not, the child would not be considered dead and could not be buried. That generated great confusion and it was kind of tragic for us (Subject 1 ).

\section{Discussion}

Understanding the meaning of brain death is one of the factors that most influence the process of organ donation, because the process of collecting, transplanting and organ donating cannot result from absence or insufficiency of potential donors, but the difficulty lies with the critical care professionals (doctors and nurses) that in order to identify a potential donor they must be aware of the definition of brain death ${ }^{(13)}$.

The diagnosis of brain death is little discussed among healthcare workers, but is present in the context of intensive care units as this is the environment in which it is possible to revive a person in such a clinical picture so that their hemodynamic functions are 
maintained in order that they may become a potential organ donor ${ }^{(14)}$.

Although the definition of brain death diagnosis is a competent responsibility of the health care team for the potential donor, some workers believe there is no legal need for complementary tests to establish the diagnosis, causing an ethical conflict in this environment ${ }^{(13)}$. This lack of understanding by workers requires technical and scientific knowledge involving understanding of the brain death concept, resuscitation, the process, diagnosis and maintenance of organs in viable conditions ${ }^{(14)}$.

Understanding the concept of brain death by the family is fundamental because families usually only hear talk about the subject when their family experiences the situation directly, hindering their acceptance, which is an understandable fact due to the complexity of such a clinical situation ${ }^{(15)}$. For some families, the patient is still perceived as alive, although brain death is already diagnosed, since the condition of the warm body is that of "the heart still beating and lungs continue to be inflating and deflating at a steady pace," the patient is kept artificially alive in the Intensive Care Unit, and this contrasts with the idea of a corpse $\mathrm{e}^{(16,7) \text {. }}$

The limited knowledge of people about the concept of brain death, coupled with the influence of the family witnessing the outer appearance of a living family member with a beating heart, and especially maintaining their body heat, breathing movements, healthy color and operation of their main systems, makes it difficult to understand and/or accept brain death and are major barriers to positive authorization for organ donation. After all, most people associate death with respiratory and cardiac arrest, a cold and motionless body ${ }^{(6)}$.

The knowledge about the need for maintenance of hemodynamic functions of potential donors involves understanding the diagnosis of brain death, the organ collection process for transplants and also the possibility of resuscitation of potential donors. It is for the health team responsible for the patient to have complete control of all hemodynamic functions of the potential donor. Thus, it is essential that health workers and particularly those in the Intensive Care Unit have not only knowledge, but a vital interest in favoring the maintenance of organs in viable conditions $^{(17)}$.

To promote the maintainance of organs in viable conditions, it is recommended that every potential donor is transferred to the Intensive Care Unit and in the event of cardiac arrest, this should be reverted as per the American Heart Association ${ }^{(18)}$. In this perspective, the discussion about the possibility of maintaining the life of a potential donor is required in the context of health workers who can characterize an ethical dilemma when these have conflicting values and principles about the concept of brain death ${ }^{(14)}$.

In addition to this factor, there are other factors that negatively influence the donation process being: ignorance of the potential donor's desire ${ }^{(6-7)}$, religion ${ }^{(7)}$, desire to keep the body intact ${ }^{(7,19)}$, donor demonstration in life contrary to the donation ${ }^{(7)}$ and family indecision about the transplant ${ }^{(19)}$.

With regard to ethical issues experienced by workers during the process of collecting organs, one of the biggest difficulties is related to the refusal of families of potential donors to donate organs and tissues, as this is a serious problem that contributes to reducing the rate of transplants ${ }^{(6-7,19)}$.

The results also showed that the acceptance of the family to donate in the case of brain-death diagnosis and the subsequent change of mind during the organ collection process is one of the most difficult ethical dilemmas to be faced by the staff of the IntraHospital Commitee for Donation of Organs and Tissues for Transplant. This condition is one of the most complex experiences highlighted by the participants of this research; when they are not comfortable in switching off devices or refuse to do so, even with 
the family's appeal, when there is a change of heart and they decide to not give the organs and tissues of their relative, which contextualizes an ethical conflict. This question puts in check the diagnosis of brain death and the relationship between society and the body, perpetuating a culture of non-acceptance of the irreversibility of brain functions, such as death of the individual, also aggravating the relationship of trust established between health professionals and the public $^{(14)}$.

The suspension of resources is not euthanasia or any kind of crime against life, given that it was an already dead patient and not terminal. The Federal Medical Council recognizes that society is not sufficiently familiar with this subject, which generates anxiety, doubts and fears, but that it should be addressed in comprehensive, humane and caring ways $^{(20)}$.

Health professionals should be aware that the shutdown of the equipment is backed by law, even against the denial of organ donation. Since October 2007, suspension of therapeutic support procedures when brain death is certain in a non-donor of organs, tissues and body parts for transplant purposes has been deemed legal and ethical. Therefore, compliance with the decision must be preceded by communication and clarification of brain death to the relatives of the patient or their legal representative, explained and recorded in the medical record, and the implementation of that resolution by the physician ${ }^{(20)}$.

In this sense, the work of the multidisciplinary team that makes up the Intra-Hospital Committee for Donation of Organ and Tissues for Transplant is essential to both encourage the process of possible donors for identifying funding and for donor agencies to implement protocols for conducting diagnostic tests, to prove the existence of brain death and notification of it, and for raising family awareness to reduce possible obstacles for effectuating transplants in Brazil.

\section{Final Considerations}

In referring to the ethical issues involved in performing activities in an Intra-Hospital Commitee for Donation of Organ and Tissues for Transplant, one of the biggest challenges is to understand the diagnosis of brain death of the potential donor. Another factor is the refusal of donation by the family, consequently causing an ethical dilemma between maintaining the potential donor in the Intensive Care Unit or not. Such situations create an ethical conflict, prompting the employee to be questioned about their attitudes and values, and to reflect on their practice as a member of a health team and life-saver. Given these facts, workers can refer to Resolution No. 1826/2007, which considers the legal and ethical suspension of therapeutic support procedures when certain brain death has been diagnosed for a non-donor of organs for transplant.

Believing and acting with ethical and caring attitudes in the donation process; understanding and respecting the autonomy of families to decide about donating is essential for an effective collection process in order to make it a positive experience for both the health team and for the family. Therefore, the building of knowledge about the experiences of an Intra-Hospital Committee for Donation of Organs and Tissues for Transplant has contributed to an awareness and understanding of the activities carried out by it, as well as the difficulties that constitute it and keep it active and effective for permanent periods in a hospital.

In this sense, the possibility of saving lives is related to the efforts of the teams, their commitment to the process, the technical and scientific knowledge about brain death, and especially the sensitivity in addressing family members of patients.

Given the lack of studies in this area, it is believed that this body of knowledge is important to promote qualitative research of other workers/rese- 
archers in the transplant area. There may be potential benefits to nursing knowledge, the quality of life of workers, donor recipients, families, society and the scientific community.

\section{Collaborations}

Cappellaro J, Silveira RS, Lunardi VL, Corrêa LVO, Sanchez ML and Saioron I contributed approval of the final version to be published.

\section{References}

1. Mendes KDS, Roza BA, Barbosa SFF, Schirmer J, Galvão CM. Transplante de órgãos e tecidos: responsabilidades do enfermeiro. Texto Contexto Enfermagem. 2012; 21(4):945-53.

2. Domingos GR, Boer LA, Possamai FP. Doação e captação de órgãos de pacientes com morte encefálica. Enferm Brasil. 2010; 9(4):206-12.

3. Freire SG, Freire ILS, Pinto JTJM, Vasconcelos QLDAQ, Torres GV. Alterações fisiológicas da morte encefálica em potenciais doadores de órgãos e tecidos para transplantes. Esc Anna Nery. 2012; 16(4):761-6.

4. Santos MJ, Massarollo CKB. Factors that facilitate and hinder family interviews in the process of donating organs and tissues for transplantation. Acta Paul Enferm. 2011; 24(4):472-8.

5. Ministério da Saúde (BR). Portaria GM/MS no․ 1.752, de 23 de setembro de 2005. Determina a constituição de Comissão Intra-Hospitalar de Doação de Órgãos e Tecidos para Transplante (CIHDOTT) em todos os hospitais públicos e filantrópicos com mais de 80 leitos. Disponível em:http://www.saude.mg.gov.br/images / documentos/Portaria_1752.pdf

6. Moraes EL, Massarollo MCKB. Reasons for the family members refuscal to donate organ and tissue for transplant. Acta Paul Enferm. 2009; 22(2)131-5.

7. Dalbem GG, Caregnato RCA. Doação de órgãos e tecidos para transplante: recusa das famílias. Texto Contexto Enferm. 2010; 19(4):728-35.
8. Associação Brasileira de Transplante de Órgãos. Entenda a doação de órgãos. Decida-se pela vida [internet]. Disponível em: http://www. abto.org.br/abtov02/portugues/populacao/ doacaoorgaostecidos/pdf/entendadoacao.pdf

9. Arcanjo RA, Oliveira LC, Silva DD. Reflexões sobre a comissão intra-hospitalar de doação de órgãos e tecidos para transplantes. Rev Bioética. 2013; 21(1):119-25.

10. Pessalacia JDR, Cortes VF, Ottoni A. Bioética e doação de órgãos no Brasil: aspectos éticos na abordagem à família do potencial doador. Bioética. 2011; 19(3):671-82.

11. Silveira RS, Martins CR, Lunardi VL, Vargas MAO, Lunardi-Filho WD, Avila LI. A dimensão moral do cuidado em terapia intensiva. Ciênc Cuid Saúde. 2014; 13(2):327-34.

12. Polit DF, Beck CT. Delineamentos e abordagens de pesquisas qualitativas. In: Polit DF, Beck CT, organizadores. Fundamentos de pesquisa em enfermagem. 7 $\underline{a}$ ed. Porto Alegre- RS: Artmed; 2011. p. 288-315

13. Silva JRF, Silva MM, Ramos VP. Familiaridade dos profissionais de saúde sobre critérios de diagnósticos de morte encefálica. Enferm Foco. 2010; 1(3):102-7.

14. Roza BA, Thomé T, Net BF, Schirmer J. Doação de órgãos e tecidos no Brasil: podemos evoluir? Mundo Saúde; 2009; 33(1):43-8.

15. Lima AAF, Silva MJP, Pereira LL. Sofrimento e Contradição: $O$ significado da morte e do morrer para enfermeiros que trabalham no processo de doação de órgãos para transplante. Enferm Global. 2009; 15(1):1-17.

16. Dell Agnolo CM, Belentani LM, Zurita RCM, Coimbra JAH, Marcon SS. A experiência da família frente à abordagem para doação de órgãos na morte encefálica. Rev Gaúcha Enferm. 2009; 30(3):375-82.

17. Zambudio AR, Martínez-Alarcón L, Parrilla P, Ramires P. Atitude of nursing staff toward organ donation in a Spanish hospital with a solid-organ transplant program. Prog Transplant. 2009; 19(4):371-7. 
18. Westphal GA, Caldeira Filho $M$, Vieira KD, Zaclikevis VR, Bartz MCM, Wanzuita R. et al. Diretrizes para manutenção de múltiplos órgãos no potencial doador adulto falecido, Parte I. Aspectos gerais e suporte hemodinâmico. Rev Bras Terapia Intensiva. 2011; 23(3):255-68.

19. Conceição MPS, Oliveira AJB, Pontes RWF, Brito NBB. Análise dos motivos para não doação de órgãos em hospital de referência na Amazônia. J Bras Neuroc. 2012; 23(2):118-22.
20. Conselho Federal de Medicina. Resolução 1.826/2007. Dispõe sobre a legalidade e o caráter ético da suspensão dos procedimentos de suportes terapêuticos quando da determinação de morte encefálica de indivíduo não-doador. Brasília: Conselho Federal de Medicina; 2007. 